DOI: http://dx.doi.org/10.33846/ghs5306

\title{
Hubungan antara Pemberian Makanan Pendamping Asi (MP-ASI) Pada Bayi Usia 0-6 Bulan dengan Gangguan Sistem Pencernaan di Wilayah Kerja Puskesmas Perawatan Kairatu
}

\author{
Harmiyati (koresponden) \\ (DIII Kebidanan, STIKes Maluku Husada; arindiah7@gmail.com) \\ Ira Sandi Tunny \\ (IImu Keperawatan, STIKes Maluku Husada) \\ Fatma Reni Wael \\ (DIII Kebidanan, STIKes Maluku Husada)
}

\begin{abstract}
ABSTRAK
Makanan pendamping ASI (MP-ASI) dini merupakan peralihan asupan yang semata berbasis susu menuju makanan semi padat pada usia 0-6 bulan, pengenalan pemberian MP-ASI harus dilakukan secara bertahap baik bentuk maupun jumlahnya, sesuai dengan kemampuan pencernaan bayi atau anak. Tujuan pada penelitian ini adalah Untuk mengetahuai "Hubungan Pemberian Makanan Pendamping Asi (MP-ASI) Pada Bayi Usia 0-6 Bulan Dengan Gangguan Sistem Pencernaan di Wilayah Kerja Puskesmas Perawatan Hila Kecamatan Leihitu Kabupaten Maluku Tengah. Penelitian ini menggunakan deskriptif analitik dengan penelitian cross sectional. Cara pengambilan sampel Dengan teknik sampling random dengan jumlah sampel 40 responden. Hasil penelitian ini menunjukan ada hubungan Pemberian Makanan Pendamping Asi (MP-ASI) Dengan Gangguan Sistem Pencernaan nilai $p<0,05$ atau $=0,000$ dengan $X^{2}$ hitung $=(1.000)>X^{2}$ tabel $(0.3120)$. Kesimpulannya bahwa ada hubungan pemberian makanan pendamping asi (MP-ASI) dengan gangguan sistem pencernaan di wilayah kerja puskesmas perawatan hila.
\end{abstract}

Kata kunci: MP-ASI; gangguan sistem pencernaan

\section{PENDAHULUAN}

\section{Latar Belakang}

Kesehatan anak adalah upaya pemeliharaan anak ditujukan untuk mempersiapkan generasi akan datang yang sehat, cerdas, dan berkualitas serta untuk menurunkan angka kematian anak. Upaya pemeliharaan kesehatan anak dilakukan sejak janin masih dalam kandungan, dilahirkan, setelah dilahirkan, dan sampai berusia 18 tahun. ${ }^{(1)}$

Bayi usia 0-6 bulan dapat tumbuh secara optimal dengan mengandalkan ASI selama 6 bulan pertama kehidupannya. Namun kenyataannya, sebelum usia 6 bulan, banyak bayi yang sudah diberi Makanan Pendamping ASI (MP-ASI).(2)

Pada tahun 2005, UNICEF dan World Health Organiation (WHO) merekomendasikan sebaiknya anak hanya disusui Air Susu Ibu (ASI) selama paling sedikit 6 bulan. Makanan padat seharusnya diberikan sesudah anak berumur 6 bulan, dan pemberian ASI dilanjutkan sampai anak berumur dua tahun. ASI eksklusif dianjurkan pada beberapa bulan pertama kehidupan karena ASI mengandung gizi yang diperlukan dan paling sesuai untuk bayi/anak. Selain itu, kebersihan ASI lebih terjamin dari pada makanan lain. ${ }^{(1)}$

Berdasarkan data Profil Kesehatan Indonesia, mengatakan tercatat bayi yang mendapatkan MP-ASI pada usia 0-6 bulan sekitar $46 \%$. dan data Profil Kesehatan RI (2017), bayi yang mendapatkan MP-ASI pada usia 0-6 bulan tercatat sekitar 38,67 \%. Sedangkan menurut Riskesdas (2018), bayi yang mendapatkan MP-ASI pada usia 0-6 bulan tercatat 62,7 \% presentasi tersebut mengalami peningkatan dibandingkan dari tahun sebelumnya. ${ }^{(3)}$

Makanan pendamping ASI (MP-ASI) dini merupakan peralihan asupan yang semata berbasis susu menuju makanan semi padat pada usia 0-6 bulan, pengenalan dan pemberian MP- ASI harus dilakukan secara bertahap baik bentuk maupun jumlahnya, sesuai dengan kemampuan pencernaan bayi atau anak. ${ }^{(4)}$

Pemberian MP-ASI secara dini dapat berdampak negatif bagi bayi yaitu hasil riset terakhir dari peneliti di Indonesia menunjukkan bahwa bayi yang mendapat MP-ASI sebelum ia berumur 6 bulan, lebih banyak terserang diare, sembelit, batuk-pilek, dan panas dibandingkan bayi yang hanya mendapatkan ASI Eksklusif. ${ }^{(5)}$

Bayi di bawah usia 6 bulan memiliki sistem pencernaan yang belum sempurna. Tubuh bayi belum memiliki protein pencernaan yang lengkap. Berbagai enzim seperti asam lambung, amilase, 
enzim yang di produksi pangkreas belum cukup ketika bayi belum berusia 6 bulan. Begitu pula dengan enzim pencernaan karbohidrat (maltase, sukrase), dan lipase untuk mencerna lemak. ${ }^{(6)}$

Untuk mencegah terjadinya gangguan pencernaan karena akibat pemberian MP ASI dini, maka MP ASI harus memenuhi syarat meliputi Tepat waktu (MP ASI mulai diberikan saat kebutuhan energi dan nutrien melebihi yang di dapat dari ASI); Adekuat (MP ASI harus mengandung cukup energi, protein, dan mikroprotein); Aman (penyimpanan, penyiapan dan sewaktu diberikan MP ASI harus higienis); Tepat cara pemberian (MP ASI diberikan sejalan dengan tanda lapar dan nafsu makan yang ditunjukan bayi serta frekuensi dan cara pemberian sesuai dengan usia bayi). ${ }^{(7)}$

\section{METODE}

Penelitian ini menggunakan deskriptif analitik dengan penelitian cross sectional dimana variable bebas dan variabel terikat dikumpulkan dalam waktu yang bersamaan. ${ }^{(8)}$ Rancangan ini dengan tujuan untuk mengetahui Hubungan Pemberian Makanan Pendamping Asi (MP-ASI) pada Bayi 0-6 Bulan dengan Gangguan sistem Pencernaan di Wilayah Kerja Puskesmas Perawatan Kairatu.

Populasi adalah wilayah generalisasi yang terdiri atas objek/subjek yang mempunyai kualitas dan karakteristik tertentu. Populasi pada penelitian ini adalah semua bayi pada usia 0-6 bulan sebanyak 68 bayi di Puskesmas Perawatan kairatu.

Dalam penelitian ini peneliti menggunakan teknik sampling random dimana Simpel random sampling adalah pengambilan anggota sampel dari populasi yang dilakukan secara acak tanpa memperhatiakan strata yang ada dalam populasi itu. ${ }^{(9)}$

Sebelum dilakukan analisis data dilakukan pengolahan data menggunakan komputer program SPSS (Statistical product and service solutions) melalui langkah-langkah sebagai berikut : editing, codeting, dan tabulasi setelah data diolah, selanjutnya untuk melihat ada atau tidaknya hubungan variabel independen dan dependen dengan menggunakan perangkat lunak computer dengan bantuan SPSS dengan uji statistik yang digunakan yaitu uji statistik Chi Square dengan nilai $\mathrm{P} \leq$ 0,05 maka $\mathrm{H} 1$ diterima, berarti ada hubungan sedangkan sebaliknya apabila $\mathrm{P}>0,05$ maka $\mathrm{H} 0$ ditolak berarti tidak ada hubungan.

\section{HASIL}

\section{Karakteristik Responden}

Tabel 1. Distribusi Karakteristik Bayi dan Ibu di Wilayah Kerja Puskesmas Perawatan Kairatu 2019

\begin{tabular}{|l|c|c|}
\hline \multicolumn{1}{|c|}{ Karakteristik } & Frekuensi & Persentase \\
\hline Karakteristik Bayi & \multicolumn{1}{|c|}{} \\
\hline Umur Bayi & 4 & 10.0 \\
\hline 1 Bulan & 4 & 10.0 \\
\hline 2 Bulan & 12 & 30.0 \\
\hline 3 Bulan & 7 & 17.5 \\
\hline 4 Bulan & 13 & 32.5 \\
\hline 5 Bulan & \multicolumn{1}{|}{} \\
\hline Jenis Kelamin & 20 & 50.0 \\
\hline Laki-Laki & 20 & 50.0 \\
\hline Perempuan & \multicolumn{2}{|}{} \\
\hline Karakteristik Ibu & 25 & 55.0 \\
\hline Umur Ibu & 18 & 45.0 \\
\hline 20-30 Tahun & 1 & 2.5 \\
\hline$>30$ Tahun & 2 & 5.0 \\
\hline Pendidikan Ibu & 22 & 55.0 \\
\hline SD & 6 & 15.0 \\
SMP & \multicolumn{1}{|l|}{11} & 22.5 \\
\hline SMA &
\end{tabular}




\begin{tabular}{|l|c|c|}
\hline \multicolumn{1}{|c|}{ Karakteristik } & Frekuensi & Persentase \\
\hline Pekerjaan Ibu & 20 & 50.0 \\
\hline IRT & 6 & 15.0 \\
\hline Wiraswasta & 14 & 35.0 \\
\hline PNS & 19 & 47.5 \\
\hline Jumlah Anak & 9 & 22.5 \\
\hline 1 Anak & 12 & 30.0 \\
\hline 2 Anak & &
\end{tabular}

Tabel 1 menjelaskan bahwa dari 40 responden dengan usia bayi yang paling terbanyak adalah usia 5 bulan yang berjumlah 13 orang. Responden pada bayi dengan jenis kelamin laki- laki sebanyak 20 orang dan yang berjenis kelamin perempuan sebanyak 20 orang dari total sampel 40 orang.

Berdasarkan hasil karakteristik ibu dengan usia terbanyak adalah 20-30 tahun. Sedangkan pada tingkat pendidikan ibu yang terbanyak adalah pada tingkat SMA. Berdasarkan pekerjaan ibu yang terbanyak adalah dengan tingkat pekerjaan sebagai IRT. Sedangkan berdasarkan jumlah anak yang paling banyak dengan 1 anak didapatkan sebanyak 19 orang, dan paling sedikit sebanyak 9 orang

\section{Pemberian Makanan Pedamping Asi (MP- ASI) Pada Bayi 0- 6 Bulan.}

Tabel 2. Distribusi Pemberian Makanan Pendamping Asi (MP-ASI) Pada Bayi Usia 0-6 Bulan di Wilayah Kerja Puskesmas Perawatan Kairatu 2019

\begin{tabular}{|c|c|c|}
\hline Pemberian Makanan Pendamping Asi (MP- ASI) Pada Bayi Usia 0-6 Bulan & $\mathrm{f}$ & $\%$ \\
\hline Tidak Diberikan & 17 & 42.5 \\
\hline Diberikan & 23 & 57.5 \\
\hline Jumlah & 40 & 100 \\
\hline
\end{tabular}

Berdasarkan tabel 2 diketahui bahwa praktik pemberian makanan pedamping Asi (MP-ASI) pada bayi usia 0-6 bulan dengan kategori tidak diberikan sebanyak 17 dan diberikan sebanyak 23.

\section{Gangguan Sistem Pencernaan}

Tabel 3. Distribusi Gangguan Sistem Pencernaan di Wilayah Kerja Puskesmas Perawatan Kairatu 2019

\begin{tabular}{|c|c|c|}
\hline Gangguan Sistem Pencernaan & $\mathrm{f}$ & $\%$ \\
\hline Tidak ada gangguan & 17 & 42.5 \\
\hline Ada Gangguan & 23 & 57.5 \\
\hline Jumlah & 40 & 100 \\
\hline
\end{tabular}

Berdasarkan tabel 3 diketahui bahwa berdasarkan gangguan sistem pencernaan didapatkan kategori tidak ada gangguan sebanyak 17 orang, dan ada gangguan sebanyak 23 orang.

\section{Hubungan Pemberian Makanan Pedamping Asi (MP-ASI) pada Bayi Usia 0-6 Bulan dengan Gangguan Sistem Pencernaan}

Berdasarkan uji Chi-square diketahui bahwa pada kategori bayi yang tidak diberikan Makanan Pendamping Asi (MP-ASI) sebayak 17 orang tidak mengalami gangguan pencernaan, sedangkan bayi yang diberikan Makanan Pendamping Asi (MP-ASI) sebanyak 23 orang dan mengalami gangguann pencernaan.

Hasil uji statistik dengan uji Chi-Square didapatkan $p$-value $=0,000$; maka dapat disimpulkan ada hubungan antara pemberian makanan pendamping asi (MP-ASI) pada bayi usia 0-6 bulan dengan gangguan sistem pencernaan yang berarti kedua variabel signifikan. 


\section{PEMBAHASAN}

\section{Pemberian Makanan Pendamping Asi (MP-ASI) Bayi Usia 0-6 Bulan}

Berdasarkan hasil penelitian didapatkan praktik pemberian makanan pedamping Asi (MP-ASI) pada bayi usia 0-6 bulan dengan kategori terbanyak diberikan MP-ASI sebanyak 23. Hasil penelitian diatas sejalan dengan penelitian yang dilakukan di Wilayah Kerja Puskesmas Bangsari Kabupaten, Hasil ini secara umum menunjukan bahwa praktik pemberian makanan tambahan pada anak usia dini kurang dari 6 bulan masih cukup tinggi. ${ }^{(10)}$

Pemberian makanan pendamping ASI dini adalah memberikan makanan selain ASI atau PASI pada bayi sebelum berusia 6 bulan. Pemberian makanan Pendamping selain asi pada bayi kurang dari 6 bulan akan memberikan dampak negatif pada bayi antara lain dimana tumbuh kembang bayi tidak akan maksimal, kekebalan tubuh bayi kurang, bayi mengalami konstipasi, diare, regurgitasi serta adanya reaksi alergi. ${ }^{(11)}$

Menurut asumsi peneliti, bahwa pemberian MP-ASI pada bayi usia 0-6 bulan di puskesmas masih cukup tinggi, dan dapat memberikan dampak negatif pada bayi karena menggalami gangguan sistem pencernaan.

\section{Gangguan Sistem Pencernaan}

Berdasarkan hasil penelitian yang dilakukan dengan kategori gangguan sistem pencernaan didapatkan kategori ada gangguan sebanyak 23 orang. Penelitian yang dilakukan juga menunjukan hasil yang sama di Wilayah Kerja Puskesmas Bangsari Kabupaten, dari 60 responden didapatkan kategori tidak sakit (sehat) yang mengalami gangguan sistem pencernaan diantaranya diare, muntah, dan konstipasi. ${ }^{(10)}$

Hasil Penelitian yang dilakukan di Desa Sukorejo Kecamatan Bangsalsari Kabupaten Jamber didapatkan kejadian regurgitasi (Gumoh). ${ }^{(13)}$ Gangguan pencernaan itu sendiri bisa diakibatkan oleh infeksi atau alergi misalnya alergi protein susu sapi, gangguan motilitas usus, gangguan keseimbangan asam basa, sumbatan usus, defi siensi enzym pencernaan atau sindroma malabsorbsi. Bayi yang berumur 0-6 bulan rentan mengalami diare, karena ezim laktosa dalam usus kerapatannya belum sempurna, sehingga sulit untuk mengurai makanan padat yang masuk karena sistem pencernaan yang belum siap. Oleh karena itu sebaiknya jangan memberikan makanan pendamping ASI terlalu dini, cukup diberikan ASI eksklusif pada anak umur sekian karena di dalam ASI terdapat anti bodi dan zat penting lainnya untuk pertumbuhan bayi. Selain diare, pada anak umur sekian juga mudah mengalami sembelit atau konstipasi, mutah dan lain sebagainya. ${ }^{(14)}$

Menurut asumsi peneliti, bahwa angka kejadian gangguan pencernaan pada bayi usia 0-6 bulan dipuskesmas masih cukup tinggi, hal ini disebabakan karena masih banyak ibu memberikan MP-ASI pada bayi tidak sesuai dengan anjuran.

\section{Hubungan Pemberian Makananan Pendamping Asi (MP-ASI) pada bayi usia 0-6 bulan dengan ganggguan sistem pncernaan}

Bayi yang diberikan Makanan Pendamping ASI (MP-ASI) mengalami gangguann pencernaan, berdasarkan hasilperhitungan SPSS Ho ditolak sehingga dapat disimpulkan ada hubungan antara pemberian makanan pendamping asi (MP-ASI) pada bayi usia 0-6 bulan dengan gangguan sistem pencernaan. Hasil ini didukung oleh penelitian yang dilakukan di Wilayah Kerja Puskesmas Bangsari Kabupaten, yang mengalami gangguan sistem pencernaan diantaranya diare, muntah, dan konstipasi. ${ }^{(10)}$

Dengan hasil uji statistik ini dapat disimpulkan adanya hubungan yang signifi kan antara pemberian makanan tambahan usia dini dengan kejadian gangguan sistem pencernaan pada bayi usia 0-6 bulan di Puskesmas Bangsri I Kecamatan.

Pemberian makanan pendamping asi salah satunya termasuk susu formula diberikan pada bayi kurang dari 6 bulan yang kurang tepat dapat menyebabkan gangguan sistem pencernaan seperti diare, muntah, regurgitasi (gumoh) atau sembelit (konstipasi) karena $80 \%$ saluran pencernaan bayi belum siap dan tidak memiliki sistem kekebalan yang baik untuk menerima makanan padat. Menurut asumsi peneliti, bahwa hubungan pemberian MP-ASI pada bayi usia 0-6 bulan dengan gangguan sistem pencernaan di puskesmas masih cukup tinggi, karena masih banyak ibu yang memberikan MP-ASI pada bayi yang tidak sesuai dengan umur dan yang dianjurkan, sehingga kedua variabel tersebut memiliki hubungan yang sangat kuat dan searah. ${ }^{(12)}$ 


\section{KESIMPULAN}

Berdasarkan hasil penelitian yang telah dilakukan pada 40 orang bayi pada usia 0-6 bulan dengan gangguan sistem pencernaan di wilayah kerja Puskesmas Perawatan Hila Kecamatan Leihitu Kabupaten Maluku Tengah, didapatkan ada hubungan antara pemberian makanan pendamping asi (MP-ASI) pada bayi usia 0-6 bulan dengan gangguan sistem pencernaan Puskesmas.

\section{DAFTAR PUSTAKA}

1. Kementerian Kesehatan RI. (2016). Profil Kesehatan Indonesia. Jakarta: Kementerian Indonesia.

2. Kasumayanti E. 2016. Hubungan Pemberian MP-ASI Dini dengan Kejadian Diare pada Bayi 0-6. Jurnal Pendidikan Anak Usia Dini, 1 (2),

3. Kemenkes. Profil Kesehatan Indonesia 2016. Jakarta: Kemenkes; 2017.

4. Chomaria, N. 2014. Panduan Super Lengkap Kehamilan Kelahiran dan Tumbuh Kembang Anak. Surakarta: Ahad Books.

5. P Eka. 2015. Hubungan Pemberian MP-ASI Pada Bayi Usia 0-6 Bulan Dengan Terjadinya Diare. Jurnal IImu Kesehatan, 4 (1).

6. Rachman, Abdul (2011) Gangguan Sistem Pencernaan Pada Bayi. http://www.pucebebe.com/Gangguan_Pencer naan_Pada_Bayi.2011.

7. Damayanti, dkk. 2011. Buku Ajar Nutrisi Pediatrik dan Penyakit Metabolik. Jakarta. Badan Penerbit IDAI

8. Natoadmojo, S. 2015, Metode Penelitian Kesehatan, Jakarta: Rineka Cipta.

9. Sugiyono. 2017. Metodologi Penelitian Kuantitatif, Kualitatif dan R\&D. Bandung: Alfabeta

10.J. Wulan. N \& Sulistiani A. 2014. Hubungan Pemberian Makanan Pendamping Asi (MP ASI) dini Dengan Kejadian Konstipasi Pada Bayi Dibawah Umur 6 Bulan.

11. Nurastrini, Vania Retno dan Kartini, Apoina. 2014. Jenis MP-ASI, Frekuensi dan Waktu Pertama Kali Pemberian MP-ASI sebagai Faktor Risiko Kejadian Gizi Lebih pada Bayi Usia 6-12 Bulan di Kota Magelang. http://ejournal- s1.undip.ac.id/index.php/jnc

12.Jumiyati. (2014) "Pemberian MPASI", URL: http://180.250.43.170:1782/poltekkes/file/MP ASI.pdf, 13.Sholihah. W. 2017. Hubungan Pemberian Susu Formula Dengan Kejadian Regurgitasi Pada Bayi Usia 1-6 Bulan di Desa Sukokerejo Kecamatan Banglalsir Jember

14.Rahmatia D. 2017. Buku Petunjuk Kesehatan Ibu dan Anak. Jakarta: Bee Media. 